\title{
Serum Vitamin D and Facial Aging: Is There a Link?
}

\author{
Noha M. Dawoud Ola A. Bakry Mohamed A. Shoeib Huda N. Ismael \\ Department of Dermatology, Andrology and STDs, Faculty of Medicine, Menoufiya University, Shebin Elkoom, Egypt
}

\section{Key Words}

Aging $\cdot$ Face $\cdot 25$-hydroxyvitamin $D \cdot$ Enzyme immunoassay

\begin{abstract}
Background: The vitamin D endocrine system, besides multiple other functions, regulates aging in many tissues, including the skin. It protects the skin against the hazardous effects of many skin age-inducing agents, including ultraviolet radiation. Thus, in the present study we aimed to investigate the relationship between facial skin aging and 25-hydroxyvitamin $\mathrm{D}[25(\mathrm{OH}) \mathrm{D}]$ serum levels in healthy Egyptian adults. Methods: Sixty-one healthy adult subjects were included. Photodamage scores (erythema/telangiectasias, lentigines, hyperpigmentation and coarse wrinkling) were assessed and graded. Serum vitamin D was measured using enzyme immunoassay and subjects were classified as sufficient, insufficient or deficient according to the vitamin level. Results: The mean 25(OH)D serum level was $43.90 \mathrm{nmol} / \mathrm{l}$. A high prevalence of vitamin $D$ deficiency was detected in the studied subjects regardless of their age or gender. Also, vitamin $D$ levels were not correlated with photodamage scores and were not affected by the Fitzpatrick skin phototype, duration of sun exposure per day or the use of sunscreens $(p>0.05$
\end{abstract}

for all). Conclusions: Aging is a complex process that is influenced by many genetic and environmental factors. Facial aging is not correlated with serum vitamin D level, and clinical trials using oral or topical vitamin $D$ to combat aging are better predictors of its effects rather than in vivo studies.

(c) 2016 S. Karger AG, Basel

\section{Introduction}

The connection between nutrition and skin condition, or rather the effect of nutrition on skin aging, has been an interesting research field for many years. The aging process is noticeable within all organs of the body, and manifests itself visibly on the skin. Skin aging is particularly important because of its social impact, and the skin also represents an ideal model organ for investigating the aging process [1]. Human skin aging can be either chronologic/intrinsic aging or extrinsic aging, of which photoaging is a major component [2].

Several forms (vitamers) of vitamin D exist (vitamin $D_{1}, D_{2}, D_{3}, D_{4}$ and $D_{5}$ ), which chemically are termed secosteroids [3]. Two of these forms, vitamin $\mathrm{D}_{2}$ and vitamin $\mathrm{D}_{3}$, are important in humans. Vitamin $\mathrm{D}_{3}$ is produced in

\section{KARGER}

E-Mail karger@karger.com

www.karger.com/spp (c) 2016 S. Karger AG, Basel

$1660-5527 / 16 / 0292-0076 \$ 39.50 / 0$
Noha Dawoud

Department of Dermatology, Andrology and STDs, Faculty of Medicine Menoufiya University

Shebin Elkoom 32817 (Egypt)

E-Mail dr_ndawoud@yahoo.com 
the skin in response to ultraviolet (UV) B radiation from sunlight or can be obtained from the diet (i.e. animal sources such as deep-sea fatty fish, egg yolks or liver) or from supplements. Both forms of vitamin $\mathrm{D}$ are converted to 25 -hydroxyvitamin $\mathrm{D}[25(\mathrm{OH}) \mathrm{D}]$ in the liver, and the serum level of $25(\mathrm{OH}) \mathrm{D}$ is measured to determine the vitamin $\mathrm{D}$ status, which is considered the best functional indicator reflecting the sum of cutaneous synthesis and oral intake [4].

The serum concentration of $25(\mathrm{OH}) \mathrm{D}$ has a fairly long circulating half-life of 15 days. Serum 25(OH)D levels do not indicate the amount of vitamin $\mathrm{D}$ stored in body tissues [5]. In contrast to $25(\mathrm{OH}) \mathrm{D}$, circulating 1,25-dihydroxyvitamin $\mathrm{D}\left[1,25(\mathrm{OH})_{2} \mathrm{D}\right]$ is generally not a good indicator of vitamin $\mathrm{D}$ status because it has a short half-life of $15 \mathrm{~h}$ and serum concentrations are closely regulated by parathyroid hormones, calcium and phosphate. Levels of $1,25(\mathrm{OH})_{2} \mathrm{D}$ do not typically decrease until vitamin $\mathrm{D}$ deficiency is severe [6].

The skin is the only tissue in the human body that represents both a target tissue for biologically active vitamin $\mathrm{D}$ compounds, including $1,25(\mathrm{OH})_{2} \mathrm{D}$, and has the capacity for the synthesis of $1,25(\mathrm{OH})_{2} \mathrm{D}$ from 7 -dehydrocholesterol. Findings indicate that the vitamin $\mathrm{D}$ endocrine system, besides multiple other important functions, regulates aging in many tissues, including the skin. The proposed link between the vitamin D endocrine system and aging is strongly supported by several independent studies in genetically modified mice [7]. Therefore, in the present study we aimed to investigate the relationship between facial skin aging and $25(\mathrm{OH}) \mathrm{D}$ serum levels in healthy Egyptian adults.

\section{Subjects and Methods}

\section{Studied Population}

This study was carried out in 61 healthy adult subjects selected from blood bank attendees. With approval of the Ethical Research Committee of Menoufiya Faculty of Medicine, written informed consent was obtained from each participant prior commencement of the study. This was in accordance with Helsinki Declaration of 1975 (revised in 2000).

\section{Exclusion Criteria}

Patients with a history of facial surgery, topical retinoid use or tanning within the last 6 months were excluded. Patients with a history of topical or systemic treatment (corticosteroids, immunosuppressive therapy, vitamin D or calcium supplementation, bisphosphonates, hepatic enzyme inducers, anticonvulsants, anticancer medication and cholesterol-lowering drugs) within 4 weeks of the study, and patients receiving phototherapy within 6 months of the study were also excluded. In addition, patients with a his- tory of diabetes mellitus, anemia, thyroid disorders, chronic liver or renal diseases, atopy or parathyroid disorders, as well as those with known autoimmune diseases or cancer, congenital or acquired errors of calcium or phosphorus metabolism were excluded. Pregnant or lactating women, obese subjects and smokers were also omitted from the study.

The documented patient data included demographics (age, gender), occupation (working outdoors or indoors), duration of sun exposure (more or less than $2 \mathrm{~h}$ daily) and history of photoprotection with sunscreens. The assessment of patient skin type was done according to Fitzpatrick skin type and the classification scale of Schmidt and Gans [8]. BMI was also calculated by dividing body weight in kilograms by the square of height in meters $\left(\mathrm{kg} / \mathrm{m}^{2}\right)$ [9].

\section{Assessment of Aging Parameter Scores}

Four parameters - erythema/telangiectasia, number of lentigines, hyperpigmentation and coarse wrinkling - were assessed on a 6-point Likert scale (from 0 , none, to 5 , very severe), which is a method of ascribing quantitative value to qualitative data in order to make it amenable to statistical analysis. The scores were dichotomized into high photodamage (3-5) versus low photodamage scores $(0-2)[10]$.

\section{Detection of Serum Vitamin D Level}

Sampling

Blood samples $(5 \mathrm{ml})$ were collected from the cubital vein in the morning under complete aseptic conditions. These were then were centrifuged at $2,500 \mathrm{rpm}$ for $15 \mathrm{~min}$ and stored at $-20^{\circ} \mathrm{C}$ until biochemical analysis. Blood sampling was done after obtaining written informed consent from the patients and control subjects, and was approved by the local ethics committee.

Determination and Interpretation of Results

Vitamin D was measured with the $25-\mathrm{OH}$ vitamin D enzyme immunoassay (EIA) kit, obtained from Immunodiagnostic AG, Bensheim, Germany, and Biomedical, Vienna, Austria. The immunodiagnostic EIA was intended for the in vitro quantitative determination of $25(\mathrm{OH}) \mathrm{D}$ in plasma and serum. The measurements were interpreted as follows: $<50 \mathrm{nmol} / \mathrm{l}$ represented deficiency, $50-74 \mathrm{nmol} / 1$ indicated insufficiency and $>75 \mathrm{nmol} / 1$ signified sufficiency [11].

\section{Statistical Analysis}

Results were collected, tabulated and statistically analyzed using an IBM personal computer and the statistical package SPSS version 11 (SPSS Inc., Chicago, Ill., USA). Data were statistically described in terms of the range, mean \pm standard deviation (SD), frequencies (number of cases) and relative frequencies (percentages), as appropriate. The Mann-Whitney U test was used for nonparametric variables that were not normally distributed and the $\chi^{2}$ test was used for categorical variables. Fisher's exact test was used for $2 \times 2$ tables when the expected cell count of more than $25 \%$ of cases was $<5$. Spearman's correlation coefficient ( $r$ ) was used to assess the correlation between two quantitative variants. Comparisons of data were made with an overall $\alpha$ error set at 0.05 (two tailed); $\mathrm{p}<0.05$ was considered significant. 
Fig. 1. Photoaging scores of the studied

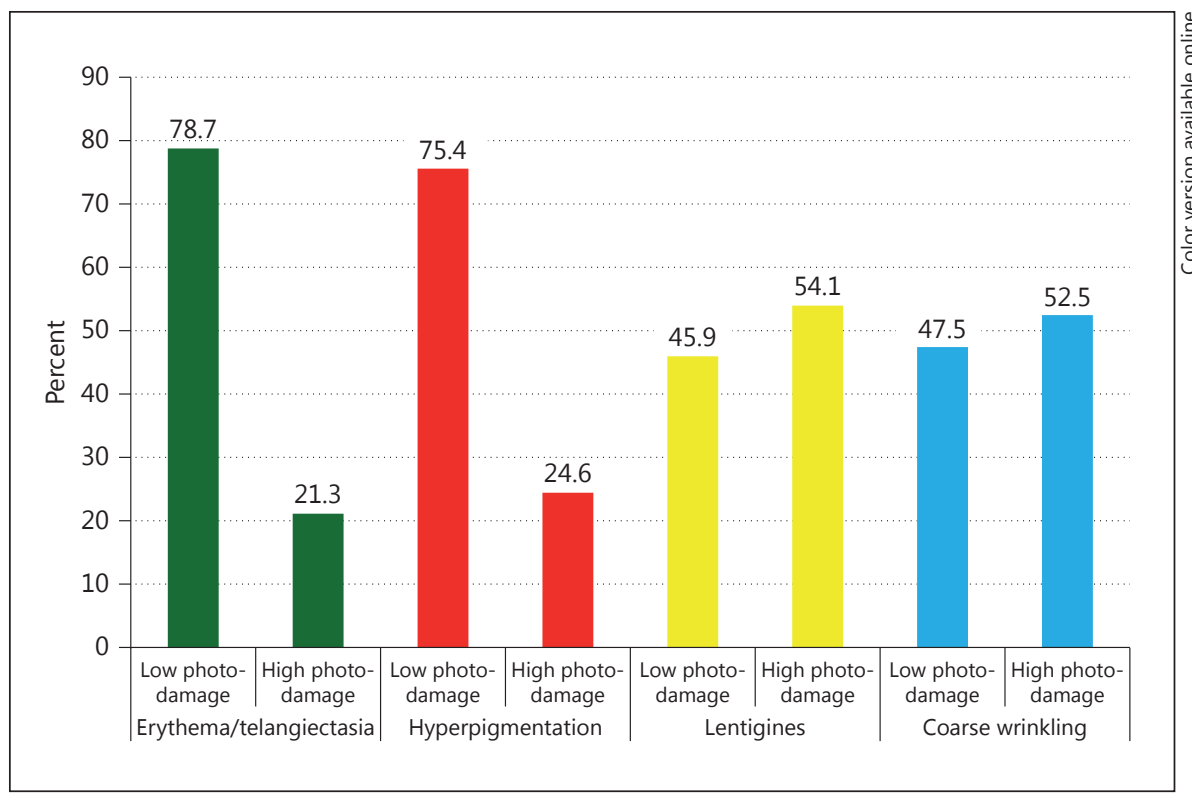
subjects.

Table 1. Clinical data of the studied subjects $(n=61)$

\begin{tabular}{lc}
\hline $\begin{array}{l}\text { Age, years } \\
\text { Mean } \pm \text { SD }\end{array}$ & $44.13 \pm 13.63$ \\
Range & $23-75$ \\
\hline BMI & $26.10 \pm 1.83$ \\
$\quad$ Mean \pm SD & $22.1-29.67$ \\
$\quad$ Range & \\
\hline Gender & $25(41.0)$ \\
Male & $36(59.0)$ \\
Female & $17(27.9)$ \\
\hline Photoprotection & $44(72.1)$ \\
Yes & \\
No & $21(34.4)$ \\
\hline Sun exposure per day & $40(65.6)$ \\
$\leq 2 \mathrm{~h}$ & \\
$>2$ h & $4(6.6)$ \\
\hline Fitzpatrick skin type & $4(66.9)$ \\
II & \\
III & \\
IV &
\end{tabular}

Values in parentheses are percentages.

\section{Results}

The clinical data and photoaging scores of the studied subjects are summarized in table 1 and figure 1, respectively.
Table 2. Vitamin D serum levels in the studied subjects $(n=61)$

\begin{tabular}{lc} 
25(OH)D, nmol/l & \\
Mean \pm SD & $43.90 \pm 32.08$ \\
Median & 31.89 \\
Range & $5.27-104$ \\
\hline 25(OH)D level, n (\%) & \\
Deficient & $39(63.9)$ \\
Insufficient & $4(6.6)$ \\
Sufficient & $18(29.5)$ \\
\hline
\end{tabular}

Vitamin D Serum Levels in the Studied Subjects

25(OH)D serum levels ranged between 5.27 and 104 $\mathrm{nmol} / \mathrm{l}$, with a mean $\pm \mathrm{SD}$ of $43.90 \pm 32.08 \mathrm{nmol} / \mathrm{l}$. Eighteen $(29.5 \%)$ subjects had normal vitamin D levels, 4 (6.6\%) had insufficient levels and 39 (63.9\%) were deficient for vitamin $\mathrm{D}$ (table 2).

\section{Relationship of Vitamin D Serum Level with Clinical}

Parameters of the Studied Subjects

No significant correlation was detected between the vitamin $\mathrm{D}$ serum level and age of the studied subjects $(p>0.05)$. Also, there was no significant correlation between the serum vitamin D level and either the photodamage score or Fitzpatrick skin type of the studied subjects ( $p>0.05$ for both).

The mean \pm SD vitamin D level was $39.59 \pm 30.5 \mathrm{nmol} / 1$ in male subjects and $46.89 \pm 33.23 \mathrm{nmol} / \mathrm{l}$ in female sub- 


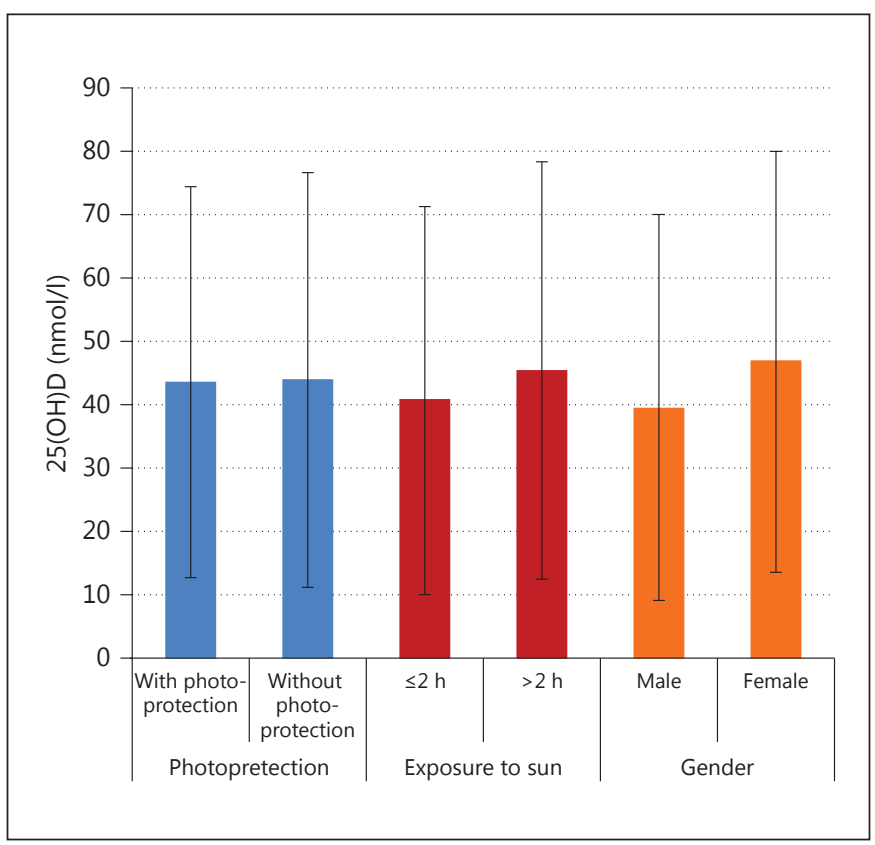

Fig. 2. Association of serum vitamin D levels in the studied subjects with gender, duration of sun exposure and photoprotection.

jects, with no statistically significant difference between the groups ( $p>0.05$; fig. 2 ). The mean $\pm S D$ vitamin $D$ level was $40.80 \pm 30.72 \mathrm{nmol} / \mathrm{l}$ for subjects with less than $2 \mathrm{~h}$ of sun exposure per day and $45.52 \pm 33.04 \mathrm{nmol} / \mathrm{l}$ for subjects exposed to sun for more than $2 \mathrm{~h}$ per day, again with no statistically significant difference between the groups ( $\mathrm{p}>0.05)$. Also, there was no significant association between the serum vitamin $\mathrm{D}$ level and photoprotection ( $p>0.05)$. The distribution of serum vitamin $D$ in the studied subjects is presented in table 3 and figure 2 . In addition, there was no significant difference in the mean serum vitamin $\mathrm{D}$ level in patients with low versus high photodamage scores of the different photoaging parameters $(\mathrm{p}>0.05$ for all; table 4$)$.

\section{Discussion}

Aging is a complex biological process at the molecular, cellular and organismal level [12]. Skin aging consists of two clinically and biologically distinct processes. The first is intrinsic skin aging, which represents chronological aging and affects skin in the same pattern as it affects all internal organs, dependent on time and reflecting the genetic background [13]. The second is extrinsic skin aging, which we view as aged skin and is the result of external factors and environmental influences, mainly chronic sun exposure and UV radiation [14].

It is well accepted that vitamin $\mathrm{D}$ compounds protect the skin against the hazardous effects of many agents that induce skin aging, including UV radiation. Several in vitro and in vivo studies have documented the protective effect of $1,25(\mathrm{OH})_{2} \mathrm{D}_{3}$ against UVB-induced skin damage and carcinogenesis [15]. Thus, the current study aimed at investigating the relationship between facial skin aging and 25(OH)D serum levels in a sample of Egyptian subjects.

The present study revealed a high prevalence of vitamin D deficiency among apparently healthy adults irrespective of their age; $63.9 \%$ were found to be vitamin D deficient and $6.6 \%$ had insufficient vitamin D. Several conditions may contribute to low serum levels of vitamin $\mathrm{D}$ in the general population, including poor dietary intake of vitamin D, sun avoidance and/or negligible sun exposure, impaired quality of life, and malabsorption due to inflammatory bowel disease, gluten enteropathy, gastric surgery, biliary disease or intestinal bacteria overgrowth [16].

Our results agree with Mansoor et al. [17], who reported a high prevalence of vitamin D deficiency in $90 \%$ of apparently healthy adult hospital staff and health care professionals. Zargar et al. [18] found that $82 \%$ of their studied healthy subjects had vitamin D deficiency. Also, O'Sullivan et al. [19] and Al-Kindi [20] reported a high prevalence of vitamin D deficiency in healthy Irish adults and Omani women, respectively.

The relationship between age and vitamin D levels is controversial. Some authors have demonstrated a correlation between age and vitamin $\mathrm{D}$ in a direct $[21,22]$ or indirect manner $[23,24]$, whereas others have found no correlation $[25,26]$. In agreement with our findings, Nichols et al. [27] did not find any association between age and vitamin $\mathrm{D}$ status in a survey of Jordanian women aged between 15 and 49 years.

However, elderly individuals can face an increased risk of vitamin D deficiency and aged skin contains considerably less vitamin $\mathrm{D}$ than younger skin. In addition, hormonal forms of vitamin $\mathrm{D}$ also decline with advancing age due to decreased synthesis and increased degradation [28]. Older adults are at increased risk of developing vitamin $\mathrm{D}$ insufficiency in part because, as they age, their skin cannot synthesize vitamin D as efficiently, they are likely to spend more time indoors and they may have inadequate intakes of the vitamin [29]. More epidemiological surveys involving different age groups are needed for stronger conclusions. 
Table 3. The distribution of serum vitamin $\mathrm{D}$ in the studied subjects $(\mathrm{n}=61)$

\begin{tabular}{|c|c|c|c|c|c|c|c|c|c|}
\hline & \multirow{2}{*}{$\begin{array}{l}\text { Males } \\
(\mathrm{n}=25)\end{array}$} & \multirow{2}{*}{$\begin{array}{l}\text { Females } \\
(\mathrm{n}=36)\end{array}$} & \multirow[t]{2}{*}{$\mathrm{p}$ value } & \multicolumn{2}{|c|}{ Exposure to sun } & \multirow[t]{2}{*}{$\mathrm{p}$ value } & \multirow{2}{*}{$\begin{array}{l}\text { With } \\
\text { photoprotection } \\
(\mathrm{n}=17)\end{array}$} & \multirow{2}{*}{$\begin{array}{l}\text { Without } \\
\text { photoprotection } \\
(\mathrm{n}=44)\end{array}$} & \multirow[t]{2}{*}{$\mathrm{p}$ value } \\
\hline & & & & $\begin{array}{l}\leq 2 \mathrm{~h} \\
(\mathrm{n}=21)\end{array}$ & $\begin{array}{l}>2 \mathrm{~h} \\
(\mathrm{n}=40)\end{array}$ & & & & \\
\hline \multicolumn{10}{|l|}{$25(\mathrm{OH}) \mathrm{D}, \mathrm{nmol} / \mathrm{l}$} \\
\hline Mean \pm SD & $39.59 \pm 30.5$ & $46.89 \pm 33.23$ & 0.44 & $40.80 \pm 30.72$ & $45.52 \pm 33.04$ & 0.61 & $43.61 \pm 30.91$ & $44.01 \pm 32.87$ & 0.75 \\
\hline Median & 30.33 & 33.16 & n.s. & 26.2 & 32.2 & n.s. & 27.58 & 32.04 & n.s. \\
\hline Range & $5.27-104$ & $6.09-98.48$ & & $5.27-96.09$ & $6.09-104$ & & $5.27-96.09$ & $6.09-104$ & \\
\hline \multicolumn{10}{|l|}{ Vitamin D level } \\
\hline Deficient & $18(72)$ & $21(58.3)$ & 0.53 & $14(66.7)$ & $25(62.5)$ & 0.66 & $12(70.6)$ & $27(61.4)$ & 0.43 \\
\hline Insufficient & $1(4)$ & $3(8.3)$ & n.s. & $2(9.5)$ & $2(5.0)$ & n.s. & $0(0.0)$ & $4(9.1)$ & n.s. \\
\hline Sufficient & $6(24)$ & $12(33.3)$ & & $5(23.8)$ & $13(32.5)$ & & $5(29.4)$ & $13(29.5)$ & \\
\hline
\end{tabular}

Values in parentheses are percentages. n.s. = Nonsignificant.

Table 4. Mean serum vitamin D levels in relation to photodamage scores of the studied subjects $(n=61)$

\begin{tabular}{lll}
\hline Photodamage scores & $25(\mathrm{OH}) \mathrm{D}, \mathrm{nmol} / \mathrm{l}$ & $\mathrm{p}$ value \\
\hline $\begin{array}{l}\text { Erythema and telangiectasia } \\
\text { Low photodamage }\end{array}$ & $45.62 \pm 32.50$ & 0.49 (n.s.) \\
$\quad$ High photodamage & $37.54 \pm 30.90$ & \\
\hline $\begin{array}{l}\text { Hyperpigmentation } \\
\quad \text { Low photodamage }\end{array}$ & $43.67 \pm 31.61$ & 0.89 (n.s.) \\
$\quad$ High photodamage & $44.57 \pm 34.61$ & \\
\hline $\begin{array}{l}\text { Lentigines } \\
\text { Low photodamage }\end{array}$ & $43.45 \pm 32.77$ & 0.95 (n.s.) \\
$\quad$ High photodamage & $44.27 \pm 31.50$ & \\
\hline Coarse wrinkling & & \\
$\quad$ Low photodamage & $43.76 \pm 31.25$ & 0.92 (n.s.) \\
$\quad$ High photodamage & $44.02 \pm 33.32$ & \\
\hline
\end{tabular}

Data are the mean \pm SD. n.s. $=$ Nonsignificant.

In the current study, there was no significant difference in vitamin $\mathrm{D}$ levels between males and females. This was in agreement with Lagunova et al. [30], who found that the prevalence of vitamin D deficiency had a similar trend in all age and gender groups. Contrary to our results, other authors noted a high prevalence of vitamin D deficiency among females $[17,31,32]$. This was explained based on less sun exposure and decreased body area exposure than the male counterparts. Hovsepian et al. [33] found a high prevalence of vitamin D deficiency (50.8\%) and insufficiency (19.6\%) in the adult population, with a higher prevalence among females. However, a meta-analysis on global vitamin D status in healthy subjects showed that women had higher vitamin D levels than men [34]. Sedrani et al. [35] showed that $70 \%$ of males had vitamin $\mathrm{D}$ deficiency compared with $30 \%$ in young females. The lower vitamin $\mathrm{D}$ levels in males than females has been explained by the combination of an increase in their body mass index, a decrease in milk consumption, which in the USA is routinely fortified with vitamin $\mathrm{D}$, and more widespread sunscreen use [36]. Therefore, we can conclude that different localities, cultural and food habits may affect serum vitamin $\mathrm{D}$ levels in both genders.

The current study did not find a significant difference in serum vitamin $\mathrm{D}$ levels among subjects regarding different skin phototypes. In contrast, Looker et al. [29] reported that the greater the amount of melanin in the epidermal layer in darker skin, the less the skin is able to produce vitamin $\mathrm{D}$ from sunlight. However, a study in Caucasian UK females showed that fair skin types had lower levels of 25(OH)D compared to darker skin types [37]. This contradiction may be due to the small number of subjects in our study and the skin phenotype of most of them $(86.9 \%)$ being type III.

Our study showed a nonsignificant correlation between serum vitamin D levels and photodamage scores. Keisala et al. [38] stated that, beside many other important functions, vitamin $\mathrm{D}$ regulates aging in skin and many other tissues. This was strongly supported by several independent studies in genetically modified mice that developed phenotypic features of premature aging, including skin and general organ atrophy in hypo- and hypervitaminosis D. Consequently, it has been hypothesized that both hypo- and hypervitaminosis D may enhance aging and that aging seems to show a U-shaped response curve to vitamin $\mathrm{D}$ status. Therefore, normovitaminosis $\mathrm{D}$ seems to be important for preventing prema- 
ture aging [7]. In addition, hairless mice that were pretreated with topical ergocalciferol 90 min before UVA irradiation were protected from the development of severe skin wrinkling and epidermal hyperplasia compared with untreated control mice [39]. This was explained by the ability of $1,25(\mathrm{OH})_{2} \mathrm{D}$ to decrease levels of pyrimidine dimer formation in the epidermis in treated mice compared with controls [40]. Richards et al. [41] studied more than 2,000 women and found that those with higher vitamin D levels showed fewer aging-related changes in their DNA. Women with higher levels of vitamin D were more likely to have longer telomeres in their cells, while lower levels correlated with shorter telomeres. Conversely, Chang et al. [42] found that women with lower photodamage scores were associated with 5 -fold increased odds of being vitamin D insufficient. This conflict may be related to differences in the demographic criteria of the studied subjects. In the studies by Chang et al. [42] and Richards et al. [41], all included subjects were females aged over 40 years, while the current study included both genders and subjects aged over 20 years. The different methods of vitamin $\mathrm{D}$ detection among the mentioned studies may have influenced the different outcome as well.

Our study did not show any significant relation between either the duration of sun exposure or the use of sun screens and $25(\mathrm{OH}) \mathrm{D}$ levels. Intentional unprotected sun exposure to increase vitamin D photosynthesis is not only unnecessary but also inefficient for populations at the highest risk of vitamin D deficiency [43]. Sun exposure is not the only determinant of vitamin D status. Individuals living at lower latitudes in relatively sunny environments are also at risk of vitamin $\mathrm{D}$ insufficiency [44]. This may be due to the fact that there is a threshold dose of UVB required to induce vitamin $\mathrm{D}$ production. However, the exact amount of UVB required for optimal vitamin $\mathrm{D}$ levels is not known as it is affected by several factors [45].

However, Giovannucci et al. [46] reported that an increased duration of sun exposure was positively correlated with vitamin D concentrations. Holick [47] found that if an individual requires 2-8 min of unprotected summer sun exposure to optimize cutaneous vitamin $\mathrm{D}$ synthesis, they could accomplish this in 10-20 min of sun exposure after applying sun protection factor 15-30 sunscreen in the customary manner. In addition, approximately 5-30 min of sun exposure between 10 a.m. and 3 p.m., at least twice a week, to the face, arms, legs or back without sunscreen usually leads to sufficient vitamin D synthesis. Sun exposure was associated with sufficient vitamin D levels in younger, normal-weight subjects and a 1-hour increase of sunlight exposure decreased the odds of being vitamin D deficient by $70 \%$ [48]. This discrepancy may be explained by differences among individuals applying sunscreens. Most Egyptian people do not use sunscreens regularly or as instructed, which may be attributed to financial factors.

In summary, the current study revealed a high prevalence of vitamin D deficiency among healthy Egyptian subjects above 20 years of age, regardless of their age and gender. Also, vitamin D level was not correlated with various photodamage scores and was not affected by Fitzpatrick skin phototype, duration of sun exposure per day or the use of sunscreens. Some inconsistencies exist between the current results and those of other studies. This can be attributed to the different criteria of the studied subjects, sample size, locality of the study, season of sampling and different methods of assessment.

There are some limitations of the present study. Since aging is a cumulative process that occurs over a long time and since the serum vitamin D level can vary over time, further prospective and/or retrospective studies over long time periods, even years, are recommended. The present work was done on a limited number of people of the same racial and ethnic background. Further large-scale multiple studies on people of different ethnicities are therefore warranted.

In conclusion, skin aging is a complex process that is influenced by many genetic and environmental factors. Clinical trials using oral or topical vitamin $\mathrm{D}$ to combat aging with close follow-up may be better predictors of its effect rather than in vivo studies. Further large-scale studies to prove or disprove the correlation of serum vitamin $D$ levels with skin aging and the effect of aging on serum vitamin D levels are needed.

\section{Disclosure Statement}

The authors declare no conflicts of interest. There were no financial sources of support for this work.
References
1 Zouboulis CC, Adjaya J, Akamatsu H, Moe- Behrens G, Niemann C: Human skin stem cells and the aging process. Exp Gerontol 2008;43:986-997.
2 Yaar M, Gilchrest BA: Photoaging: mecha- nism, prevention and therapy. Br J Dermatol 2007; 157:874-887.
3 Hollis DW: Assessment of vitamin D nutri- tional and hormonal status: what to measure and how to do it. Calcif Tissue Int 1996;58: $4-5$. 
4 Thacher TD, Clarke BL: Vitamin D insufficiency. Mayo Clin Proc 2011;86:50-60.

5 Jones G: Pharmacokinetics of vitamin D toxicity. Am J Clin Nutr 2008;88:582-586.

6 Holick MF: Vitamin D deficiency. N Engl J Med 2007;357:266-281.

7 Reichrath J: Unravelling of hidden secrets: the role of vitamin D in skin aging. Dermatoendocrinology 2012;4:241-244.

8 Schmidt N, Gans H: Clindamycin 1.2\% tretinoin $0.025 \%$ gel versus clindamycin gel treatment in acne patients: a focus on Fitzpatrick skin types. J Clin Aesthet Dermatol 2011;4: $31-40$.

9 Donohoue P: Obesity; in Angel A, Roncari D, Hollenberg C (eds): Nelson Textbook of Pediatrics, ed 17. Philadelphia, Saunders, 2004, pp 167-173.

10 Baral N, Heinen JT: Resource use, conservation attitudes, management intervention and park-people relations in the Western Terai Iandscape of Nepal. Environ Conserv 2007; 34:1-9.

11 Holick MF, Binkley NC, Bischoff-Ferrari HA Gordon CM, Hanley DA, Heaney RP, Murad $\mathrm{MH}$, Weaver CM: Evaluation, treatment, and prevention of vitamin D deficiency: an Endocrine Society clinical practice guideline. J Clin Endocrinol Metab 2011;96:1911-1930.

12 Tuohimaa P: Vitamin D and aging. J Steroid Biochem Mol Biol 2009;114:78-84.

13 Farage MA, Miller KW, Elsner P, Maibach HI Intrinsic and extrinsic factors in skin aging: a review. Int J Cosmet Sci 2008;30:87-95.

14 Ristow M, Schmeisser S: Extending life span by increasing oxidative stress. Free Radic Biol Med 2011;51:327-336.

15 Dixon KM, Deo SS, Wong G, Slater M, Norman AW, Bishop JE, Posner GH, Ishizuka S, Halliday GM, Reeve VE, Mason RS: Skin cancer prevention: a possible role of $1,25 \mathrm{dihy}-$ droxyvitamin D3 and its analogs. J Steroid Biochem Mol Biol 2005;97:137-143.

16 DeLuca HF: Overview of general physiologic features and functions of vitamin D. Am J Clin Nutr 2004;80:1689-1696.

17 Mansoor S, Habib A, Ghani F, Fatmi Z, Badruddin S, Mansoor S, Siddiqui I, Jabbar A: Prevalence and significance of vitamin D deficiency and insufficiency among apparently healthy adults. Clin Biochem 2010;43:14311435.

18 Zargar AH, Ahmad S, Masoodi SR, Wani AI Bashir MI, Laway BA, Shah ZA: Vitamin D status in apparently healthy adults in Kashmir Valley of Indian subcontinent. Postgrad Med J 2007;83:713-716.

19 O'Sullivan M, Nic Suibhne T, Cox G, Healy M, O’Morain C: High prevalence of vitamin $\mathrm{D}$ insufficiency in healthy Irish adults. Ir J Med Sci 2008; 177:131-134.

20 Al-Kindi MK: Vitamin D status in healthy Omani women of childbearing age: study of female staff at the Royal Hospital, Muscat, Oman. Sultan Qaboos Univ Med J 2011;11: 56-61.
21 Bischof MG, Heinze G, Vierhapper H: Vitamin $\mathrm{D}$ status and its relation to age and body mass index. Horm Res 2006;66:211-215.

22 Moan J, Lagunova Z, Lindberg FA, Porojnicu AC: Seasonal variation of 1,25-dihydroxyvitamin D and its association with body mass index and age. J Steroid Biochem Mol Biol 2009; 113:217-221.

23 Rucker D, Allan JA, Fick GH, Hanley DA: Vitamin $\mathrm{D}$ insufficiency in a population of healthy western Canadians. CMAJ 2002;166: 1517-1524.

24 Ockene IS, Chiriboga DE, Stanek EJ, Harmatz MG, Nicolosi R, Saperia G, Well AD, Freedson P, Merriam PA, Reed G, Ma Y, Matthews CE, Herbert JR: Seasonal variation in serum cholesterol levels: treatment implications and possible mechanisms. Arch Intern Med 2004; 164:863-870.

25 Kudlacek S, Schneider B, Peterlik M, Leb G, Klaushofer K, Weber K, Woloszczuk W, Willvonseder R: Assessment of vitamin D and calcium status in healthy adult Austrians. Eur J Clin Invest 2003;33:323-331.

26 Orgaz-Molina J, Buendía-Eisman A, ArrabalPolo MA, Ruiz JC, Arias-Santiago S: Deficiency of serum concentration of 25-hydroxyvitamin D in psoriatic patients: a case-control study. J Am Acad Dermatol 2012;67:931-938.

27 Nichols EK, Khatib IM, Aburto NJ, Sullivan KM, Scanlon KS, Wirth JP, Serdula MK: Vitamin D status and determinants of deficiency among nonpregnant Jordanian women of reproductive age. Eur J Clin Nutr 2012;66:751756.

28 Lanske B, Razzaque MS: Vitamin D and aging: old concepts and new insights. J Nutr Biochem 2007;18:771-777.

29 Looker AC, Johnson CL, Lacher DA, Pfeiffer CM, Schleicher RL, Sempos CT: Vitamin D status: United States, 2001-2006. NCHS Data Brief 2011;59:1-8.

30 Lagunova Z, Porojnicu AC, Lindberg F, Hexeberg S, Moan J: The dependency of vitamin D status on body mass index, gender, age and season. Anticancer Res 2009;29:3713-3720.

31 Atli T, Gullu S, Uysal AR, Erdogan G: The prevalence of vitamin $D$ deficiency and effects of ultraviolet light on vitamin D levels in elderly Turkish population. Arch Gerontol Geriatr 2005;40:53-60.

32 Goswami R, Kochupillai N, Gupta N, Goswa$\mathrm{mi}$ D, Singh N, Dudha A: Presence of $25(\mathrm{OH})$ $D$ deficiency in a rural North Indian village despite abundant sunshine. J Assoc Physicians India 2008;56:755-757.

33 Hovsepian S, Amini M, Aminorroaya A, Amini P, Amini P, Iraj B: Prevalence of vitamin $\mathrm{D}$ deficiency among adult population of Isfahan City, Iran. J Health Popul Nutr 2011; 29:149-155.

34 Hagenau T, Vest R, Gissel TN, Poulsen CS, Erlandsen M, Mosekilde L, Vestergaard P Global vitamin D levels in relation to age, gender, skin pigmentation and latitude: an ecologic meta-regression analysis. Osteoporos Int 2009;20:133-140.
35 Sedrani SH, Elidrissy AW, El Arabi KM: Sunlight and vitamin D status in normal Saudi subjects. Am J Clin Nutr 1983;38:129-132.

36 Looker AC, Pfeiffer CM, Lacher DA, Schleicher RL, Picciano MF, Yetley EA: Serum 25-hydroxyvitamin D status of the US population: 1988-1994 compared with 2000-2004. Am J Clin Nutr 2008;88:1519-1527.

37 Glass D, Lens M, Swaminathan R, Spector TD, Bataille V: Pigmentation and vitamin D metabolism in Caucasians: low vitamin D serum levels in fair skin types in the UK. PLoS One 2009;4:e6477.

38 Keisala T, Minasyan A, Lou YR, Zou J, Kalueff AV, Pyykko I, Tuohimaa P: Premature aging in vitamin $\mathrm{D}$ receptor mutant mice. J Steroid Biochem Mol Biol 2009;115:91-97.

39 Mitani H, Naru E, Yamashita M, Arakane K, Suzuki T, Imanari T: Ergocalciferol promotes in vivo differentiation of keratinocytes and reduces photodamage caused by ultraviolet irradiation in hairless mice. Photodermatol Photoimmunol Photomed 2004;20:215-223.

40 Dixon KM, Deo SS, Norman AW, Bishop JE Halliday GM, Reeve VE, Mason RS: In vivo relevance for photoprotection by the vitamin $D$ rapid response pathway. J Steroid Biochem Mol Biol 2007;103:451-456.

41 Richards JB, Valdes AM, Gardner JP, Paximadas D, Kimura M, Nessa A, Lu X, Surdulescu GL, Swaminathan R, Spector TD, Aviv A: Higher serum vitamin D concentrations are associated with longer leukocyte telomere length in women. Am J Clin Nutr 2007;86: 1420-1425.

42 Chang AL, Fu T, Amir O, Tang JY: Association of facial skin aging and vitamin $\mathrm{D}$ levels in middle-aged white women. Cancer Causes Control 2010;21:2315-2316.

43 Need AG, Morris HA, Horowitz M, Nordin C: Effects of skin thickness, age, body fat, and sunlight on serum 25-hydroxyvitamin D. Am J Clin Nutr 1993;58:882-885.

44 Jacobs ET, Alberts DS, Foote JA, Green SB, Hollis BW, Yu Z, Martinez ME: Vitamin D insufficiency in southern Arizona. Am J Clin Nutr 2008;87:608-613

45 Highwood EJ, Kinnersley RP: When smoke gets in our eyes: the multiple impacts of atmospheric black carbon on climate, air quality and health. Environ Int 2006;32:560-566.

46 Giovannucci E, Liu Y, Rimm EB, Hollis BW, Fuchs CS, Stampfer MJ, Willett WC: Prospective study of predictors of vitamin D status and cancer incidence and mortality in men. J Natl Cancer Inst 2006;98:451-459.

47 Holick MF: Vitamin D deficiency. N Engl J Med 2007;357:266-281.

48 Vallianou N, Bountziouka V, Akalestos T, Evangelopoulos A, Voqiatzakis E, Bonou M, Barbetseas J, Avqerinos PC, Panaqiotakos DB: Vitamin D status and health correlates among apparently healthy participants in an urban, sunny region. Cent Eur J Public Health 2012;20:262-269. 